\title{
Contrasting responses of small mammals to fire and topographic refugia
}

\author{
MATTHEW SWAN ${ }^{1 *}$, CAROLINA GALINDEZ-SILVA $^{1}$, FIONA CHRISTIE $^{1}$, ALAN $^{-}$
}

YORK $^{1}$ AND JULIAN DI STEFANO ${ }^{1}$

Fire Ecology and Biodiversity Group, School of Ecosystem and Forest Sciences, University of Melbourne, Creswick, Victoria 3363 Australia

*Corresponding Author

4 Water St Creswick,

Victoria 3363 Australia

Email:swanm@unimelb.edu.au

Ph: 0353214184

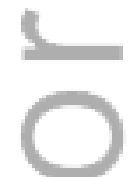

Running Title: Small mammal responses to patchy fire

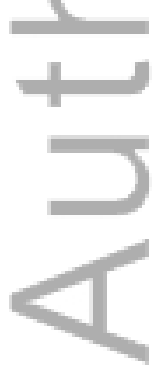

This is the author manuscript accepted for publication and has undergone full peer review but has not been through the copyediting, typesetting, pagination and proofreading process, which may lead to differences between this version and the Version of Record. Please cite this article as doi:

This article is protected by copyright. All rights reserved. 


\section{Abstract}

Unburnt patches within burnt landscapes are expected to provide an important resource for fauna, potentially acting as a refuge from direct effects of fire, and allowing animals to persist in burnt landscapes. Nevertheless there is little information about the way refugia are used by fauna and how populations may be affected by them. Planned burns are often patchy, with unburnt areas generally associated with gully systems providing a good opportunity to study faunal use of refugia. We used a before-after-control-impact design associated with a planned burn in south eastern Australia to investigate how two small mammal species, the bush rat Rattus fuscipes and agile antechinus Antechinus agilis, used unburnt gully systems within a larger burnt area. We tested three alternative hypotheses relating to post-fire abundance: 1 . Active refugia - abundance would increase in unburnt patches due to a post-fire shift of individuals from burnt to unburnt areas 2. Passive refugia abundance in unburnt patches would remain similar to pre-fire levels, and, 3. Limited or no refugia - abundance would reduce in unburnt patches related to the change induced by fire in the wider landscape. We found the two species responded differently to the presence of unburnt refugia in the landscape. Relative to controls, fire had little effect on bush rat abundance in gullies, supporting hypothesis 2 . In contrast, agile antechinus abundance increased in gullies immediately post-fire consistent with a shift of individuals from burnt parts of the landscape, supporting hypothesis 1 . Differences in site fidelity, habitat use and intraspecific competition between these species are suggested as likely factors influencing 
responses to refugia. The way unburnt patches function as faunal refugia, and the subsequent influence they have on post-fire population dynamics, will, to some extent, depend on the life history attributes of individual species.

Key Words: Disturbance, Succession, Unburnt patches, Gully, Planned burning

\section{Introduction}

Fire is a spatially heterogeneous disturbance, with variation in severity and the occurrence of unburnt patches observed in a range of different vegetation types and at various spatial scales (Delong and Kessler 2000; Penman et al. 2007; Robinson et al. 2013; RománCuesta et al, 2009). Unburnt patches, which are commonly observed after both planned fire and wildfire, are thought to be important for fauna, potentially providing refugia (Leonard et al. 2014). Refugia, defined as features that facilitate the survival or persistence of organisms in the face of a disturbance event that would otherwise result in mortality, displacement or extinction, potentially ameliorate the effects of a fire by allowing fauna to survive its immediate effects, persist in the burnt landscape and recolonise unburnt areas (Robinson et al. 2013).

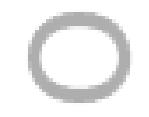

Different species may vary in their temporal and spatial use of refugia depending on vin life history strategies, home range size, mobility and habitat requirements. For example swamp wallabies Wallabia bicolor have been found to use unburnt wet gullies for short periods of time to avoid injury from the heat of fire but then to quickly move back into burnt areas after fire (Garvey et al. 2010). In contrast, some species may be confined to refugia 
until surrounding habitat becomes suitable (Lunney et al. 2008), while others use the contrasting resources provided by a mosaic of burnt and unburnt patches (Fraser et al. 2003; Körtner et al. 2007; Letnic 2001). How animal species use refugia may have implications for intra- and inter-specific competition for resources, community composition, population structure and ultimately longer-term survival and recolonisation of burnt areas (Whelan 1995). For many animal species however there are few empirical data on the use of refugia within burnt landscapes.

Planned burning provides a good opportunity to study faunal use of refugia. It is increasingly used as a management tool across many fire-prone landscapes to reduce fuel and minimise the risk of wildfire to human life and property (Fernandes and Botelho 2003). It is also often used to achieve ecological objectives such as biodiversity conservation, forest regeneration and invasive species control (Penman et al. 2011). In eucalypt forests of southeastern Australia many planned burns are carried out with the objective of reducing surfacelevel fine fuels, and elevated fuel such as shrubs and bark whilst leaving the canopy unburnt, and as such they are usually carried out in autumn or spring when conditions are mild and fuel moisture is variable (Catling 1991). As a result spatial heterogeneity in burn coverage is commonly observed, with unburnt patches often associated with wetter vegetation in gullies and on south facing slopes (Penman et al. 2007). 
Understanding the function of unburnt refugia for biota is important given the increasing application of planned fire across forests of south-eastern Australia (Enright and Fontaine 2014). Small mammals provide a good model for studying the use of refugia. In flammable systems, many small mammal species are reliant on vegetation that is consumed by fire. Further, their dispersal capacity is limited and their home ranges are often small in comparison to the size of burnt areas (Catling 1991). As such, survival within the burn perimeter immediately post-fire is likely to depend on the presence of unburnt vegetation (Catling et al. 2001; Fox 1982). Previous studies have shown that unburnt gullies within fire boundaries contain residual populations of small mammals (Irvin et al. 2003; Lunney et al. 2008). Few studies, however, have pre-fire data, and those that do often focus on changes at burnt sites rather than changes to populations in unburnt refugia (e.g. Thompson et al. 1989) Therefore it is often unclear what effect fire has on populations within refugia. For example, it is important to know whether unburnt patches contain residual populations from before fire or whether shifts of individuals from burnt to unburnt patches occur (Whelan 1995).

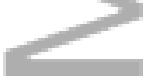

\section{2.}

In this study we used an experimental framework focussed on a single planned fire and a nearby unburnt control area to quantify the short-term effects of patchy fire on spatial abundance patterns of small mammals. We tested three alternative hypotheses about the function of unburnt patches as refugia (Table 1).

\section{Methods}


Study area

This study was conducted in the Otway Ranges in southern Victoria, Australia (Fig. 1). The climate of this region is temperate with cool wet winters and warm dry summers, with an annual mean rainfall of approximately $1180 \mathrm{~mm}$ at the nearest weather station at Mount Cowley (based on 14 years of data) (Bureau of Meteorology 2015). We focussed on two areas as part of this project; a 400 ha area scheduled for planned burning (impact area) and a 300 ha unburnt control. The control and impact areas were approximately six kilometres apart and at low elevation (100 m to $200 \mathrm{~m}$ above sea level). They shared similar topographical characteristics with major ridgelines and gullies running east west. Both areas comprised two vegetation types in similar proportions, wet forest and foothill forest (Cheal 2010). Wet forest predominantly occurs alongside creeks and gullies, while the drier, foothills forest occurs on ridges and slopes. Foothill forest in the two areas was dominated by messmate, Eucalyptus obliqua, mountain grey-gum E. cypellocarpa and blue gum E. Globulus in the overstorey. The understorey is dominated by austral bracken Pteridium esculentum dense wire grass Tetrarrhena juncea thickets and a range of dense shrubs such as hop goodenia Goodenia ovata and prickly currant bush Coprosma quadrifida. The overstorey of wet forest in the study area is similar to foothill forest, with a midstorey of blackwood Acacia melanoxylon. The main difference between the two vegetation types is the understorey which is dominated by rough tree fern Cyathea australis and ground ferns such as mother shield fern Polystichum proliferum in wet forest.

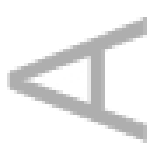


Both impact and control areas had a similar fire history having both been burnt in 1983 and 1939. The impact area was burnt as part of the land management agencies' planned burning activities from 30 - 31 March 2012. The fire was lit from the road boundaries using edge ignition with drip torches and in the middle of the burn block with aerial incendiaries.

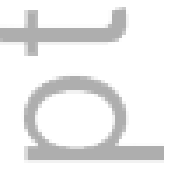

Study species

We focussed on two small mammal species, the bush rat Rattus fuscipes (Muridae) and the agile antechinus Antechinus agilis (Dasyuridae) two of the most commonly encountered, and studied, species in south-eastern Australia (Dickman and Steeves 2004). Three further species, the swamp rat Rattus lutreolus (Muridae), eastern pygmy-possum, Cercartetus nanus (Burramyidae) and dusky antechinus Antechinus swainsonii (Dasyuridae) were present in the study area, but were captured at too few sites to be formally included in the analysis (Appendix 1).

\section{(2.}

The bush rat is an omnivorous murid rodent that occurs in a wide range of vegetation types in eastern Australia (Breed and Ford 2007). It is primarily terrestrial and uses runways in dense vegetation to forage on a range of items including seeds, fungi and invertebrates (Dickman and Woodside 1983). Breeding takes place in summer with very few females breeding a second year. Juveniles disperse approximately 200 - $400 \mathrm{~m}$ from their natal territories in autumn (Robinson 1987). Adult females are highly territorial (Peakall et al. 2003). 
The agile antechinus is a small carnivorous marsupial that is common in coastal forests, woodlands and upland forest in south-eastern Australia (Dickman et al. 1998). It is partly arboreal, nesting in tree hollows and foraging primarily on the ground for invertebrates (Lazenby-Cohen and Cockburn 1991). It has a semelparous mating strategy with all males dying after the late winter breeding season (Lee and Cockburn 1985). Weaning takes place in mid-summer with males dispersing shortly thereafter in January - February and females remaining close to their natal territories (Banks et al. 2005; Cockburn et al. 1985). There is overlap in home ranges between and within sexes, with multiple adults often sharing nests (Lazenby-Cohen and Cockburn 1991).

Site selection

We conducted sampling at a series of sites across both impact and control areas. Individual sites consisted of $100 \mathrm{~m}$ linear transects. Sites were approximately $70 \mathrm{~m}$ apart and grouped in clusters of three, with one running along a gully and two running parallel on a lower midslope and upper midslope. Sites within clusters were positioned (a) so that individuals could move between them and (b) to facilitate a gradient of decreasing fire severity from upper midslope to gully locations. There were eight clusters in the impact area and four in the control area (Fig. 1). The number of clusters differed between the two areas due to limited availability of appropriate gully sites in the control area. 
Cluster locations were selected using a stratified random procedure, with the proviso that the angle of slope was less than 30 degrees and the upper slope site was a minimum of 50 metres from a vehicle track. We set a minimum distance of 350 metres between clusters to minimise the chances of individual animals moving between them. The clusters were placed so that the midslope sites were split evenly between northerly and southerly aspects (Fig. 1).

\section{Mammal surveys}

Surveys were conducted four times in both the control and impact areas, twice before fire (October 2011 and January 2012) and twice after fire (May 2012 and October 2012). Both October surveys were after male Antechinus die-off, so only adult females with pouch young were present in the sample. We used 15 small aluminium Elliott traps (Type A: $10 \mathrm{~cm}$ $\times 10 \mathrm{~cm} \times 33 \mathrm{~cm}$ ) at each site for four consecutive nights in each survey season to capture small mammals. Traps were placed approximately seven metres apart along the $100 \mathrm{~m}$ transect and, where possible, in locations considered likely to be encountered by animals such as adjacent to logs, runways or dense vegetation. Traps were baited with a mixture of peanut butter, oats, golden syrup and pistachio essence. A handful of unbleached cotton was added to provide insulation and plastic bags were placed over the traps for protection in inclement weather. Individuals were marked uniquely with liquid paper on the base of the tail to detect recaptures within each trapping season. For bush rats, individual animals were ear clipped uniquely to identify the site where they were first captured, enabling us to detect movement between sites in subsequent seasons. This method was abandoned after the first trapping 
session for agile antechinus because the ear clips could not be reliably identified in subsequent seasons, therefore movements could not be analysed for this species.

\section{Data ahalysis}

We conducted the analysis in three stages. In the first stage we used a before-aftercontrol-impact design to investigate the effects of fire and topographic position on abundance of both species. In the second stage we focussed on the on the intra-burn effects of fire on species abundance. In the third stage we focussed on the movement of bush rats after fire.

\section{The effect of fire and topographic position on abundance}

We used number of individuals per 100 trap nights as a measure of abundance to standardise for effort as there were 10 occasions where at least one trap in a transect was disturbed by larger animals and was not available to capture small mammals. We used a Gaussian distribution as residual plots suggested that this was appropriate.

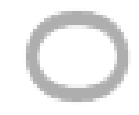

We modelled the effects of three categorical predictors, treatment (control or impact), time (before and after) and position (gully or midslope) using Generalised Linear Mixed Modelling (GLMM) with site nested within cluster as the random effect to account for spatial nestedness and repeat surveys. Midslope sites were included in the analysis regardless of their burnt status. Before and after data included the two pre-fire and two post fire samples for the 
bush rat, however we only used the survey data collected immediately before and immediately after fire (January and May) in the analysis for the antechinus because the October samples contained too many zeros to be analysed meaningfully (Appendix 1). We also investigated aspect (north or south facing midslopes) but this was subsequently discarded as preliminary analysis showed that it was not influential. We compared models containing these terms and their additive and interactive combinations using an information theoretic approach where those with lower values of Akaike's information criterion (AIC) were considered best (Burnham and Anderson 2002). We also calculated Akaike weights (w) to indicate the relative likelihood that a particular model was the best in the set (Burnham and Anderson 2002). Modelling was undertaken in the R statistical environment (R Core Team 2015) using the package lme4 (Bates et al. 2015). We calculated variance explained $\left(\mathrm{R}^{2}\right)$ as a measure of model fit using the methods outlined in Nakagawa and Schielzeth (2013) in the R package MuMin (Barton 2015). Marginal $\mathrm{R}^{2}$ values refer to the variance explained by the fixed factors alone and conditional $\mathrm{R}^{2}$ is the variance explained by both the fixed and random effects. In total 13 alternative models were investigated for each species. The effect of fire is represented by the time $\times$ treatment interaction and the effect of fire and topography is represented by a 3-way interaction, time $\times$ treatment $\times$ position.

2. Intra-burn effects of fire on species abundance

This part of the analysis was conducted only for the impact area. The response variable was the before - after difference in abundance of agile antechinus and bush rats at each site. We used Gaussian errors after pooling the two pre-fire and post-fire abundances. 
We investigated one predictor variable percentage of site burnt, as we believed it represented an important aspect of the change in resource availability attributable to the fire. Values of this variable were estimated using a handheld GPS (GARMIN GPSMAP 62s, Olathe, Kansas, USA) to measure the length of each 100 m transect line where the ground vegetation was burnt. We used a GLMM to model the effect of this variable with cluster as a random effect to account for spatial nestedness.

\section{Bush rat movement}

After fire, we counted the number of individual animals that were captured in unburnt gully sites after being captured previously in burnt midslope sites. We also counted the total number of new (not captured before fire) individual bush rats in each of the unburnt gully sites at both impact and control areas. We tested for the effect of treatment on the number of new individuals appearing in gullies using a GLMM with cluster as a random effect. We used a Poisson distribution after checking for over dispersion.

\section{Results}

Post-fire assessments found that $48 \%$ of the impact area was burnt (192 ha) and $52 \%$ remained unburnt (208 ha) (Sitters et al. 2015). The fire was of low intensity; mostly the ground and elevated fuels (up to $4 \mathrm{~m}$ ) and some bark were burnt with very little canopy scorch across the burn block. All gully sites remained unburnt. Of the 16 midslope sites, three were unburnt, eight were partially burnt along the length of the transect and five were burnt completely (Appendix 2). 
The effect of fire and topographic position on abundance

We captured 640 individual bush rats and 402 agile antechinus in over 8000 trap nights. For both species the best model for predicting abundance included the interaction between time, treatment and topographical position, indicating that the fire effect was dependent upon topography (Table 2). However, the interaction manifested differently for the two species. For bush rats there was a reduction of 4.1 (95 \% CI 2.42-5.79, $p<0.001)$ individuals per 100 trap nights on the midslope sites from before to after fire (Fig. 2). There was no change, however, in the abundance of bush rats in the gullies after fire $(0.11,95 \% \mathrm{CI}$ $-2.27-2.49, \mathrm{p}=0.93)$. In contrast to bush rats, there was no change in antechinus abundance on midslopes from before to after fire $(1.7,95 \%$ CI -6.8-3.5, $p=0.5)$ but abundance increased by 6.0 (95 \% CI 2.4-9.7, p <0.01) individuals per 100 trap nights from before to after fire in gullies (Fig. 3).
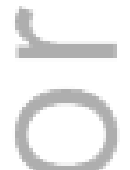

Intra-burn effects of fire on abundance

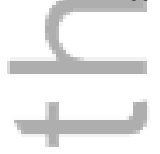

There was a significant negative relationship between the percentage of transect burnt at each site and before - after change in abundance for both the agile antechinus (estimate = 0.12, $\mathrm{SE}=0.02, \mathrm{p}<0.001$, Marginal $\mathrm{R}^{2}=0.57$; Fig. 4a) and the bush rat (estimate $=-0.15$, 
$\mathrm{SE}=0.03, \mathrm{p}<0.001$; Marginal $\mathrm{R}^{2}=0.53$ Fig. $4 \mathrm{~b}$ ). The relationship was different for the two species however, with the slope passing through the $\mathrm{x}$-axis at five for the bush rat and 60 for the agile antechinus highlighting that reductions in abundance occurred at different percentages of transect burnt (Fig. 4). Agile antechinus abundance increased in seven out of eight unburnt gully sites and many midslope sites that were either completely unburnt or only partially burnt saw increases in abundance. Five midslope sites that completely burnt had reductions in abundance of this species. For bush rats there was variability in the change in abundance for gully and midslope sites that remained completely unburnt with six sites increasing in abundance and five sites decreasing. Abundance of bush rats was reduced at all sites that were at least partially burnt.

\section{Bush rat movement}

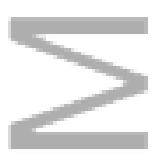

There was only one instance of an individual bush rat moving from a burnt midslope site to an unburnt gully site after fire. There was no difference in the average number of new unmarked individuals/100 trap nights captured after fire between the impact and control gullies (Impact $=4.2$, Control $=3.0$, Difference 1.2, $95 \%$ CI -1.0-3.9, $p=0.3$ ).

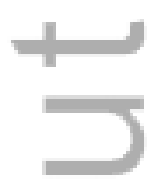

\section{Discussion}


This study has provided insights into mammal responses to patchy fire by showing that unburnt patches function differently as refugia for the two species examined. For agile antechinus, we found support for the active refugia hypothesis, with an increase in abundance in gullies and unburnt midslope sites immediately after fire. In the case of bush rats unburnt patches mainly provided habitat for individuals that were already occupying those areas before the fire, supporting the passive refugia hypothesis.

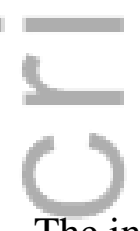

The increase of agile antechinus in gullies was quite marked, doubling from before to after fire. Also, this was not confined to gullies, the analysis of intra-burn effects of fire showed increases in abundance in many midslope sites that were either unburnt or only partially burnt. This is consistent with movement of animals from burnt midslopes to unburnt areas as a response to fire. Given that we were not able to follow movement of individual animals however, we cannot be certain of the origin of the new animals occupying the gullies after fire. It seems likely that they moved from more uniformly burnt parts of the burn area, as sites that were completely burnt had reductions in abundance. It is possible that individuals moved into unburnt patches within the burn area from outside the burn block through dispersal as juvenile males are known to disperse over $1 \mathrm{~km}$ (Banks et al. 2005). However, the fire occurred in late March which is after the documented post-weaning dispersal period of January-February (Banks et al. 2005; Cockburn et al. 1985) so it seems unlikely that the additional individuals had dispersed into the burn block from other areas. 
In contrast to agile antechinus, the fire resulted in a decrease in bush rat abundance on midslopes, but there was no apparent change in gullies, indicating passive use of refugia in this species. This hypothesis is further supported by the movement data which showed that only one individual moved from a burnt midslope to an unburnt gully after fire, and the number of unmarked individuals captured after fire was similar to gullies in the control area suggesting that there was no systematic influx of animals into gullies. The fact that abundance decreased on burnt sites proportionally to the amount of vegetation burnt indicates that this species was more sensitive to the short-term effects of fire than the antechinus.

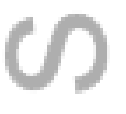

There is uncertainty in the cause of the reduction in abundance on burnt midslopes in both species. It could be from direct loss of individuals from the fire, death in the immediate aftermath or from emigration from the burnt area (Sutherland and Dickman 1999). These processes are not mutually exclusive and additional data are required to quantify their relative influence. Previous studies have indicated that small mammal species such as bush rats are unlikely to be killed directly by fire (especially low intensity fire), but often perish due to predation and starvation as a result of loss of vegetative cover (Recher et al. 2009; Thompson et al. 1989).

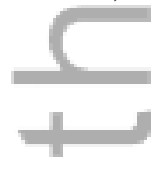

We suggest that differences in the way these two species use habitat influenced the contrasting function of unburnt patches as refugia. Bush rats are known to rely on dense ground vegetation and may be more susceptible to predation and starvation without dense 
vegetative cover in the immediate post-fire environment. Antechinus however are known to be partially arboreal (Lazenby-Cohen and Cockburn 1991) and, given that much of the canopy and midstorey remained unburnt, could potentially have used these resources to a greater degree. This may have led to antechinus being more able to survive the early postfire period in order to move into unburnt patches. Also foraging resources in the form of bark invertebrates, which have been shown to be little affected by low intensity fires in this forest type (Heaver 2013), may have facilitated persistence of this species in the short term.

In addition to differences in habitat use, difference in intraspecific competition between these two species may also have influenced their use of refugia. Antechinus are known to tolerate home range overlap and adults often share nests and utilise large social ranges (Lazenby-Cohen and Cockburn 1991). This might allow them to be flexible in allowing midslope dwellers to move into unburnt gullies after fire. Adult bush rats on the other hand are highly territorial and it may be more difficult for them to move out of their home ranges due to encounters with conspecifics. Other studies have shown this species to have high home range fidelity in the face of disturbance (Thompson et al. 1989). This could be related to avoidance of territorial encounters as individuals living in fragmented landscapes shifted home ranges when resident individuals were experimentally removed (Holland and Bennett 2011). 
Whilst we consider intraspecific interactions and habitat use patterns to be the most likely drivers of our results, the effect of interspecific interactions cannot be discounted entirely. The agile antechinus and bush rat are known to be outcompeted by the dusky antechinus and swamp rat respectively (Dickman 1986; Maitz and Dickman 2001). The dusky antechinus was present in low numbers in both gully and midslope sites across the landscape before and after fire. It is possible that resource limitation caused by fire resulted in direct competition between the two Antechinus species in some areas within the burn block. However the fact that there was an increase in agile antechinus abundance in gullies where dusky antechinus abundance was highest, makes it unlikely that interference competition was especially influential in driving the observed patterns. Bush rats were unlikely to be significantly influenced by swamp rats in this particular study because they were only present at a very small number of sites in one isolated part of the burn block. Whilst there is little evidence of interspecific interactions driving use of refugia in this study, this may not hold for other parts of Australia where relative abundances of these species are different. For example higher abundances of dusky antechinus could potentially restrict the use of unburnt patches as active refugia for agile antechinus. Repeating this study in different areas with varying abundances of these species would help to elucidate the role of competitive interactions.

Developing a good understanding of how species respond to patchy disturbances is further complicated by potential interactions between species life history characteristics which influence their use of refugia and the spatial and temporal dynamics of the unburnt 
patches which act as refugia. For example a study on retention islands within logging coupes found that agile antechinus abundance in retained patches was similar to before logging and to control unharvested areas indicating that there was no active refuge effect like that observed in the present study (Lindenmayer et al. 2010). This highlights that the use of refugia may be context specific and potentially influenced by their size and arrangement, and intensity of the adjacent disturbance.

\section{Conclusion}

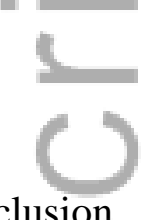

In this study we found that patchy fire affected two small mammal species differently and this distinction could not have been made without pre-fire data used in an experimental framework. Pre-fire data are critical, as the way unburnt patches function as refugia cannot be determined without them (Banks et al. 2011; Sutherland and Dickman 1999). Admittedly, this study lacked replication at the burn block level and as such the results cannot be extrapolated beyond the study area. This highlights the need for further research that uses planned fire as part of an experimental framework, preferably with multiple replicate planned burns, however this is logistically difficult to implement (Driscoll et al. 2010). In doing so, such research would help to elucidate the role of fire severity and the size and spatial arrangement of unburnt patches on species fire responses. 


\section{Acknowledgments}

We thank John Loschiavo, Erin Steel, Holly Sitters, Amanda Ashton, Evan Watkins, Tina Camm, Rachel Lloyd, Cathy Weiss, Haydn Swan and Magda Kvasnicka for field assistance and Paul McCoughtry and Jenny Howell for assistance with site selection and burn planning. Two anonymous reviewers helped to improve this manuscript. This research was supported by the Department of Environment and Primary Industries (DEPI), Parks Victoria and the Holsworth Wildlife Research Endowment. Field work was conducted under the National Parks Act (Research Permit Number 10005348) and Forests Act (Scientific Permit Number 10005514), and faunal surveys were approved by the University of Melbourne School of Land and Environment Ethics Committee (Register No. 1011632.5).

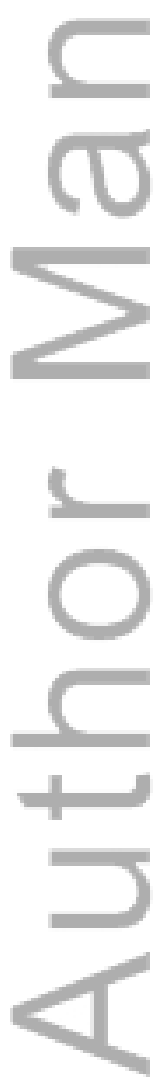




\section{References}

Banks S. C., Dujardin M., McBurney L., Blair D., Barker M. \& Lindenmayer D. B. (2011) Starting points for small mammal population recovery after wildfire: recolonisation or residual populations? Oikos 120, 26-37.

Banks S. C., Ward S. J., Lindenmayer D. B., Finlayson G. R., Lawson S. J. \& Taylor A. C. (2005) The effects of habitat fragmentation on the social kin structure and mating system of the agile antechinus, Antechinus agilis. Mol. Ecol. 14, 1789-801.

Barton K. (2015) MuMIn: Multi-model inference. R package version 1.14.0 http://CRAN.Rproject.org/package=MuMIn.

Bates D., Maechler M., Bolker B. \& Walker S. (2015) Linear mixed-effects models using Eigen and S4. R package version 1.1-8 http://CRAN.R-project.org/package=lme4.

Breed B. \& Ford F. (2007) Native mice and rats. CSIRO Publishing, Melbourne.

Bureau of Meteorology. (2015) Climate statistics for Australian Locations. <http://www.bom.gov.au/climate/data/?ref=ftr $>$.

Burnham K. P. \& Anderson D. R. (2002) Model selection and multimodel inference: $a$ practical information-theoretic approach. Springer, New York.

Catling P. C. (1991) Ecological effects of prescribed burning practices on the mammals of southeastern Australia. In: Conservation of Australia's Forest Fauna (ed D. Lunney) pp. 35363. Royal Zoological Society of New South Wales, Sydney.

This article is protected by copyright. All rights reserved. 
Catling P. C., Coops N. C. \& Burt R. J. (2001) The distribution and abundance of grounddwelling mammals in relation to time since wildfire and vegetation structure in south-eastern Australia. Wildlife. Res. 28, 555-64.

Cheal D. (2010) Growth stages and tolerable fire intervals for Victoria's native vegetation datasets. In: Fire and Adaptive Management Report No. 84. Department of Sustainability and Environment, East Melbourne, Victoria.

Cockburn A., Scott M. P. \& Scotts D. J. (1985) Inbreeding avoidance and male-biased natal dispersal in Antechinus spp. (Marsupialia: Dasyuridae). Anim. Behav. 33, 908-15.

Delong S. C. \& Kessler W. B. (2000) Ecological characteristics of mature forest remnants left by wildfire. Forest Ecol. Manag. 131, 93-106.

Dickman C. R. (1986) An experimental manipulation of the intensity of interspecific competition: Effects on a small marsupial. Oecologia 70, 536-43.

Dickman C. R., Parnaby H. E., Crowther M. S. \& King D. H. (1998) Antechinus agilis (Marsupialia: Dasyuridae), a new species from the A. stuartii complex in south-eastern Australia. Aust. J. Zool. 46, 1-26.

Dickman C. R. \& Steeves T. E. (2004) Use of habitat by mammals in eastern Australian forests: are common species important in forest management? In: Conservation of Australia's Forest Fauna (ed D. Lunney) pp. 761-73. Royal Zoological Society of New South Wales, Sydney.

Dickman C. R. \& Woodside D. P. (1983) A test of a competition model with reference to three species of small mammals in south-eastern Australia. Oecologia 60, 127-34.

Driscoll D. A., Lindenmayer D. B., Bennett A. F., Bode M., Bradstock R. A., Cary G. J., Clarke M. F., Dexter N., Fensham R., Friend G., Gill M., James S., Kay G., Keith D. A., 
MacGregor C., Russell-Smith J., Salt D., Watson J. E. M., Williams R. J. \& York A. (2010) Fire management for biodiversity conservation: Key research questions and our capacity to answer them. Biol. Conserv. 143, 1928-39.

Enright N. J. \& Fontaine J. B. (2014) Climate change and the management of fire-prone vegetation in southwest and southeast Australia. Geographical Research 52, 34-44.

Fernandes P. M. \& Botelho H. S. (2003) A review of prescribed burning effectiveness in fire hazard reduction. Int. J. Wildland Fire. 12, 117-28.

Fox B. J. (1982) Fire and mammalian secondary succession in an Australian coastal heath. Ecology 63, 1332-41.

Fraser B. F., Lawson V., Morrison S., Christophersen P., McGreggor S. \& Rawlinson M. (2003) Fire management experiment for the declining Partridge Pigeon, Kakadu National Park. Ecological Management \& Restoration 4, 94-102.

Garvey N., Ben-Ami D., Ramp D. \& Croft D. B. (2010) Survival behaviour of agile wallabies during prescribed burning and wildfire. Wildlife. Res. 37, 1-12.

Heaver A. M. (2013) The effects of fire on bark habitats and associated beetle assemblages PhD Thesis. University of Melbourne.

Holland G. J. \& Bennett A. F. (2011) Recolonization of forest fragments by a native rodent following experimental 'extinctions'. Austral Ecol. 36, 521-9.

Irvin M., Westbrooke M. \& Gibson M. (2003) Effects of repeated low-intensity fire on terrestrial mammal populations of a mixed eucalypt foothill forest in south-eastern Australia. Fire Management, Department of Sustainability and Environment, Melbourne.

Körtner G., Pavey C. R. \& Geiser F. (2007) Spatial ecology of the mulgara in arid Australia: impact of fire history on home range size and burrow use. Journal of Zoology 273, 350-7. 
Lazenby-Cohen K. A. \& Cockburn A. (1991) Social and foraging components of the home range in Antechinus stuartii (Dasyuridae: Marsupialia). Aust. J. Ecol. 16, 301-7.

Lee A. K. \& Cockburn A. (1985) Evolutionary ecology of marsupials. Cambridge University Press, Cambridge.

Leonard S. W. J., Bennett A. F. \& Clarke M. F. (2014) Determinants of the occurrence of unburnt forest patches: Potential biotic refuges within a large, intense wildfire in southeastern Australia. Forest Ecol. Manag. 314, 85-93.

Letnic M. (2001) Long distance movements and the use of fire mosaics by small mammals in the Simpson Desert, central Australia. Aust. Mammal 23, 125-34.

Lindenmayer D. B., Knight E., McBurney L., Michael D. \& Banks S. C. (2010) Small mammals and retention islands: An experimental study of animal response to alternative logging practices. Forest Ecol. Manag. 260, 2070-8.

Lunney D., Lunney H. \& Recher H. F. (2008) Bushfire and the Malthusian guillotine: survival of small mammals in a refuge in Nadgee Nature Reserve, south-eastern New South Wales. Pacific Conservation Biology 14, 263-78.

Maitz W. \& Dickman C. (2001) Competition and habitat use in native Australian Rattus: is competition intense, or important? Oecologia 128, 526-38.

Nakagawa S. \& Schielzeth H. (2013) A general and simple method for obtaining R2 from generalized linear mixed-effects models. Methods. Ecol. Evol. 4, 133-42.

Peakall R., Ruibal M. \& Lindenmayer D. B. (2003) Spatial autocorrelation analysis offers new insights into gene flow in the Australian bush rat, Rattus fuscipes. Evolution 57, 118295. 
Penman T. D., Christie F. J., Andersen A. N., Bradstock R. A., Cary G. J., Henderson M. K., Price O., Tran C., Wardle G. M., Williams R. J. \& York A. (2011) Prescribed burning: how can it work to conserve the things we value? Int. J. Wildland Fire. 20, 721-33.

Penman T. D., Kavanagh R. P., Binns D. L. \& Melick D. R. (2007) Patchiness of prescribed burns in dry sclerophyll eucalypt forests in South-eastern Australia. Forest Ecol. Manag. 252, 24-32.

R Core Team. (2015) R: A language and environment for statistical computing. http://www.R-project.org/.

Recher H. F., Lunney D. \& Matthews A. (2009) Small mammal populations in a eucalypt forest affected by fire and drought. I. Long-term patterns in an era of climate change. Wildlife. Res. 36, 143-58.

Robinson A. C. (1987) The ecology of the bush rat, Rattus fuscipes (Rodentia: Muridae), in Sherbrooke Forest, Victoria. Aust. Mammal 11, 35-49.

Robinson N. M., Leonard S. W. J., Ritchie E. G., Bassett M., Chia E. K., Buckingham S., Gibb H., Bennett A. F. \& Clarke M. F. (2013) Refuges for fauna in fire-prone landscapes: their ecological function and importance. J. Appl. Ecol. 50, 1321-9.

Román-Cuesta R. M., Gracia M. \& Retana J. (2009) Factors influencing the formation of unburned forest islands within the perimeter of a large forest fire. Forest Ecol. Manag. 258, $71-80$.

Sitters H., Di Stefano J., Christie F. J., Sunnucks P. \& York A. (2015) Bird diversity increases after patchy prescribed fire: implications from a before-after control-impact study. Int. J. Wildland Fire. 24, 690-701. 
Sutherland E. F. \& Dickman C. R. (1999) Mechanisms of recovery after fire by rodents in the Australian environment: a review. Wildlife. Res. 26, 405-19.

Thompson M. B., Medlin G., Hutchinson R. \& West N. (1989) Short-term effects of fuel reduction burning on populations of small terrestrial mammals. Australian Wildlife Research 16, $117-29$.

Whelan R. J. (1995) The Ecology Of Fire. Cambridge University Press, Cambridge

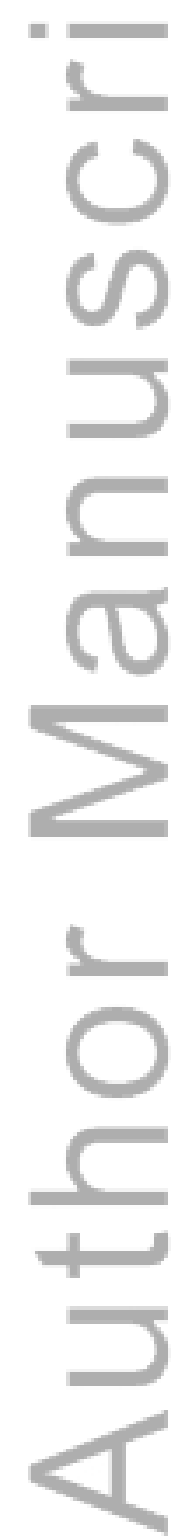

This article is protected by copyright. All rights reserved. 
Table 1. A hypothetical framework for the use of refugia within burnt landscapes by small mammals

\begin{tabular}{|c|c|c|}
\hline Hypothesis & General Description & Specific prediction \\
\hline Active refugia & $\begin{array}{l}\text { Animals from burnt areas move } \\
\text { into unburnt areas to either } \\
\text { survive fire or persist after fire }\end{array}$ & $\begin{array}{l}\text { Fire results in increased abundance } \\
\text { in unburnt patches }\end{array}$ \\
\hline Passive refugia & $\begin{array}{l}\text { Population size within internal } \\
\text { refuges remains unchanged by } \\
\text { fire. Individuals living in burnt } \\
\text { areas either perish or emigrate } \\
\text { from the burnt area }\end{array}$ & $\begin{array}{l}\text { Fire has no effect on abundance in } \\
\text { unburnt patches }\end{array}$ \\
\hline $\begin{array}{l}\text { Limited o } \\
\text { refugia }\end{array}$ & $\begin{array}{l}\text { Unburnt areas do not provide a } \\
\text { refuge from the effects of fire } \\
\text { resulting in a reduction in } \\
\text { abundance in unburnt patches } \\
\text { related to the change induced by } \\
\text { fire in the wider landscape. }\end{array}$ & $\begin{array}{l}\text { Fire results in reduced abundance } \\
\text { or local extinction in unburnt } \\
\text { patches }\end{array}$ \\
\hline
\end{tabular}


Table 2. Model selection statistics for the BACI analysis of small mammal abundance. Models were ranked using Akaike's information criterion (AIC).

\begin{tabular}{lllll}
\hline & & Akaike & Marginal & Conditional \\
Model & $\mathbf{\Delta a i c}$ & Weight & $\mathbf{R}^{2}$ & $\mathbf{R}^{2}$ \\
\hline Bush Rat & & & & \\
time * treatment * position & 0 & 0.74 & 0.33 & 0.55 \\
time * treatment + position & 3.1 & 0.16 & 0.30 & 0.51 \\
time + treatment + position & 6.0 & 0.04 & 0.28 & 0.49 \\
time * position & 6.4 & 0.03 & 0.23 & 0.50 \\
time + position & 7.5 & 0.02 & 0.22 & 0.49 \\
time + treatment * position & 8.0 & 0.01 & 0.28 & 0.49 \\
treatment + position & 12.1 & 0.00 & 0.25 & 0.45 \\
position & 13.6 & 0.00 & 0.19 & 0.45 \\
treatment * position & 14.1 & 0.00 & 0.25 & 0.45 \\
time * treatment & 20.5 & 0.00 & 0.11 & 0.51 \\
time + treatment & 23.5 & 0.00 & 0.09 & 0.49 \\
time & 25.0 & 0.00 & 0.02 & 0.48 \\
treatment & 29.51 & 0.00 & 0.06 & 0.45 \\
& & & & \\
Agile Antechinus & & & & \\
time * treatment * position & 0 & 0.99 & 0.34 & 0.48 \\
time + treatment * position & 10.46 & 0.01 & 0.28 & 0.38 \\
treatment * position & 12.32 & 0.00 & 0.26 & 0.35 \\
time * treatment + position & 14.13 & 0.00 & 0.25 & 0.37 \\
time + treatment + position & 14.83 & 0.00 & 0.25 & 0.38 \\
time * position & 16.23 & 0.00 & 0.13 & 0.45 \\
treatment + position & 16.77 & 0.00 & 0.22 & 0.34 \\
time * treatment & 18.65 & 0.00 & 0.19 & 0.36 \\
time + treatment & 19.43 & 0.00 & 0.19 & 0.37 \\
treatment & 21.44 & 0.00 & 0.17 & 0.33 \\
time + position & 22.2 & 0.00 & 0.08 & 0.38 \\
position & 24.21 & 0.00 & 0.06 & 0.34 \\
time & 26.87 & 0.00 & 0.03 & 0.37 \\
\hline & & & &
\end{tabular}




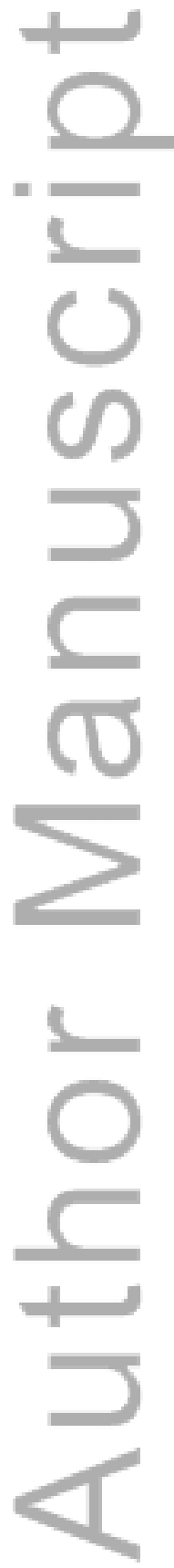

This article is protected by copyright. All rights reserved. 


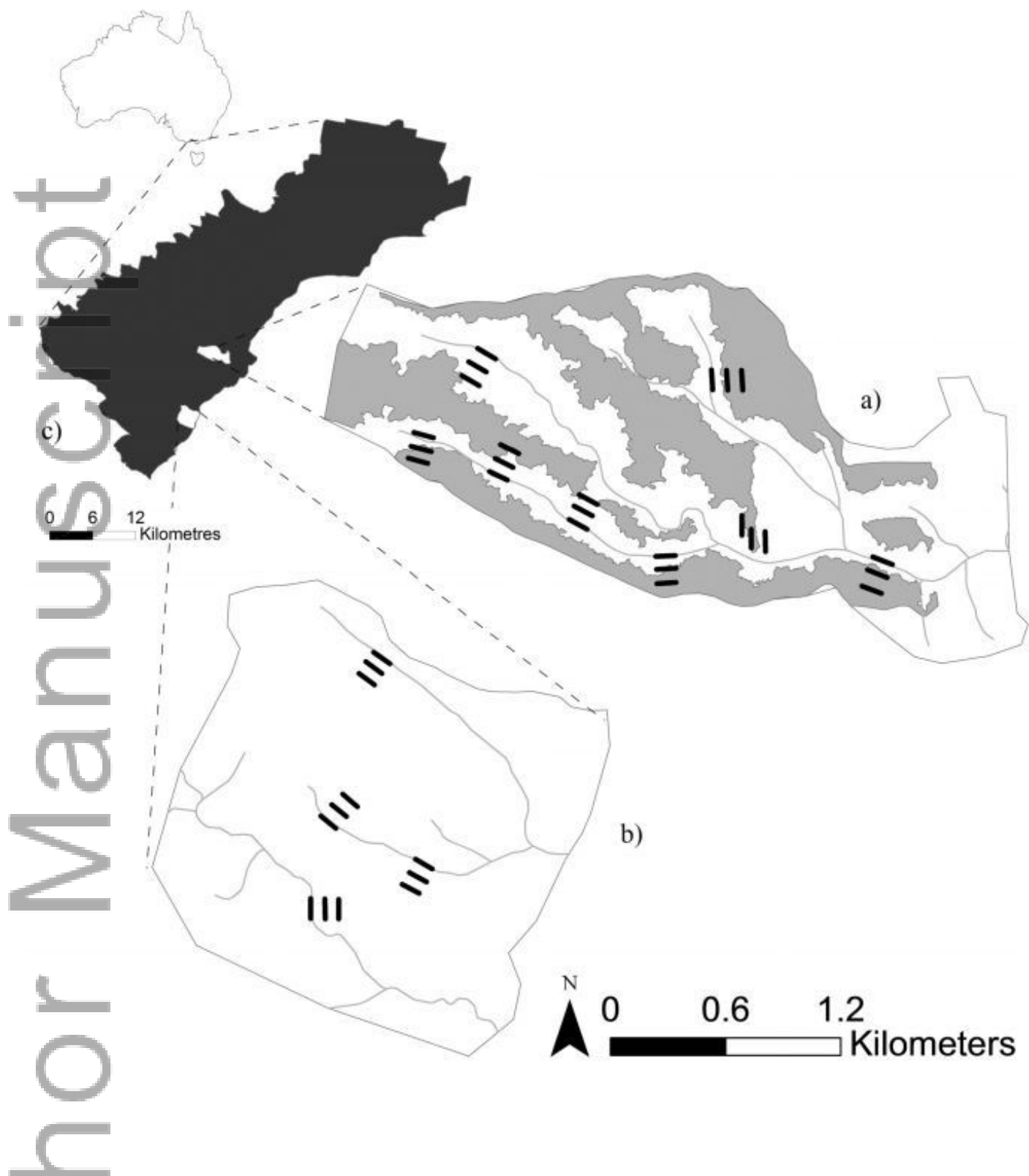

Fig. 1. The impact area (a) and control area (b) within the Otway Ranges study area (c) in southern Australia. The three parallel black lines represent sites within a cluster. Grey lines within each area represent gullies. The grey shaded area within the impact area is the footprint of the burn conducted in March 2012.

This article is protected by copyright. All rights reserved. 

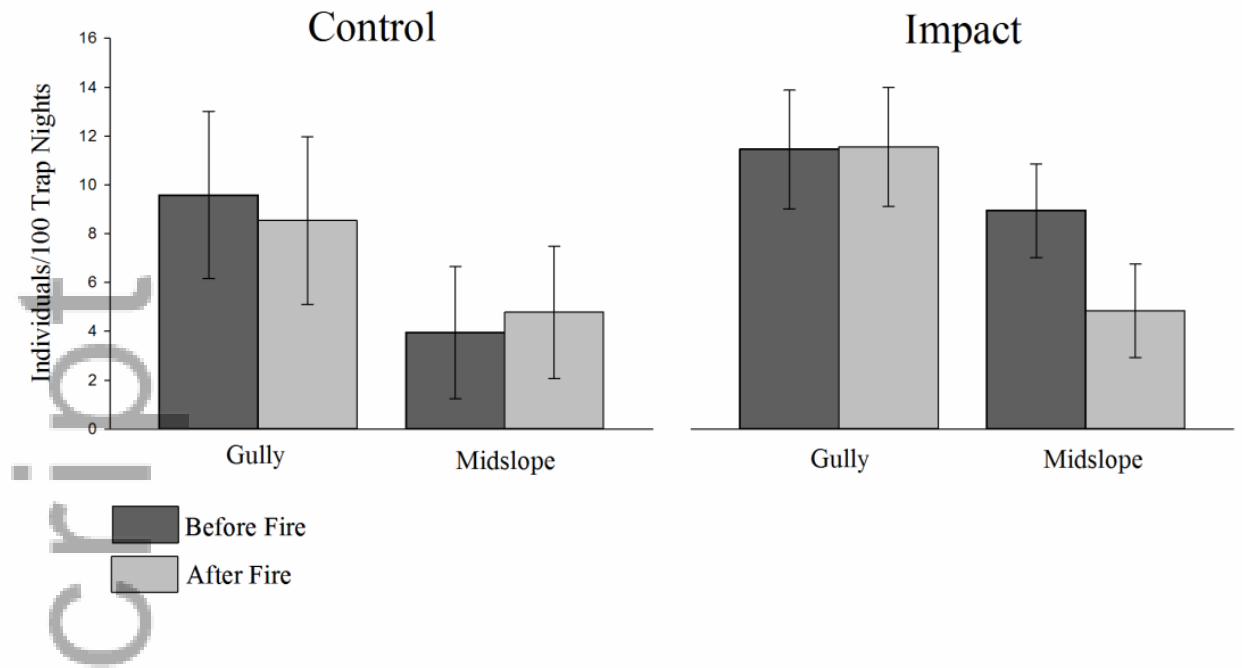

Fig. 2. Mean abundance of bush rats in gully and midslope sites of the control and impact areas before and after fire. Error bars represent $95 \%$ confidence limits.

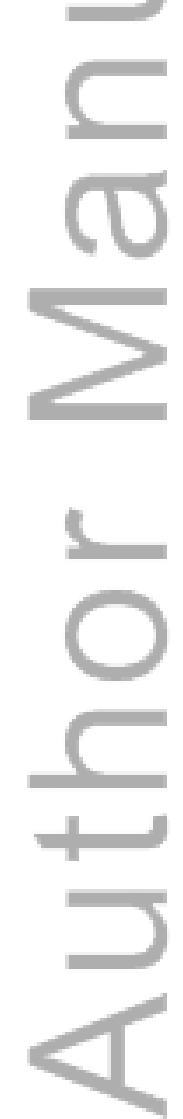

This article is protected by copyright. All rights reserved. 


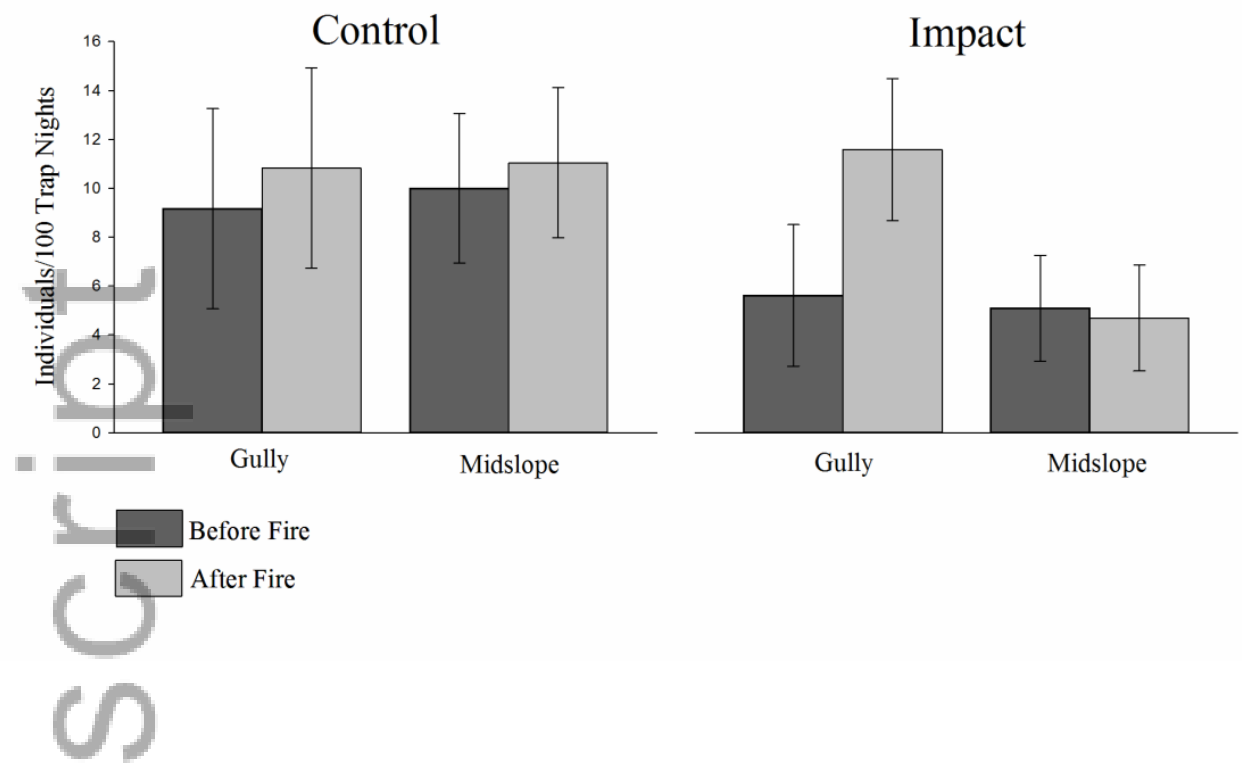

Fig.3. Mean abundance of agile antechinus in gully and midslope sites of the control and impact areas before and after fire. Error bars represent 95 \% confidence limits.

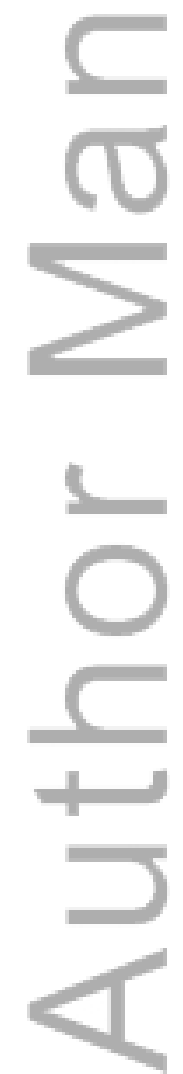

This article is protected by copyright. All rights reserved. 


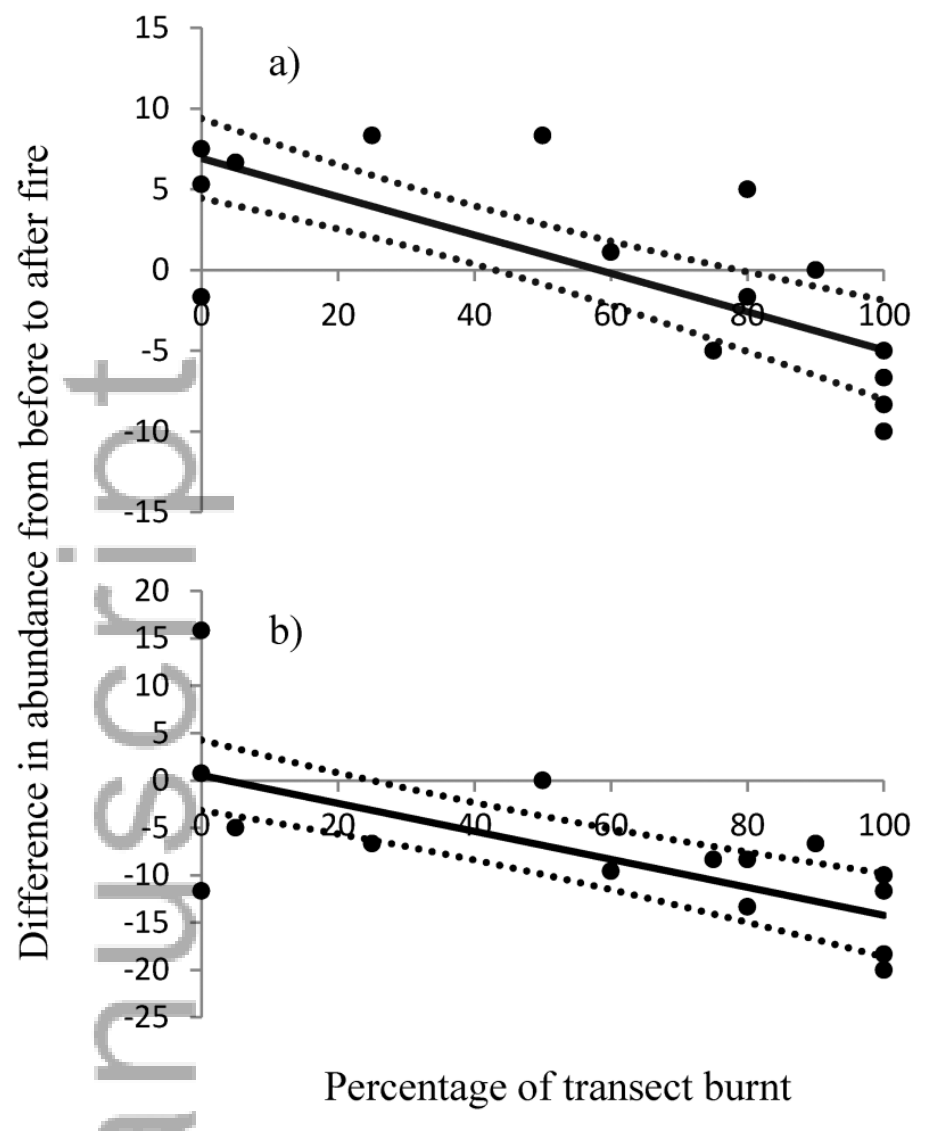

Fig. 4. Relationships between percentage transect burnt and change in abundance from before to after fire for agile antechinus (a) and bush rat (b). Only data points from midslope sites are shown for clarity. A positive value on the y-axis represents an increase in abundance after the fire. Error lines represent $95 \%$ confidence limits.

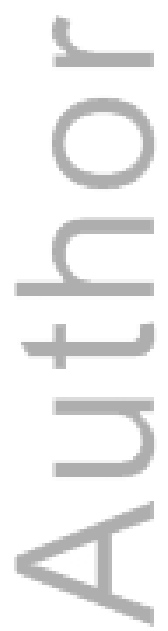



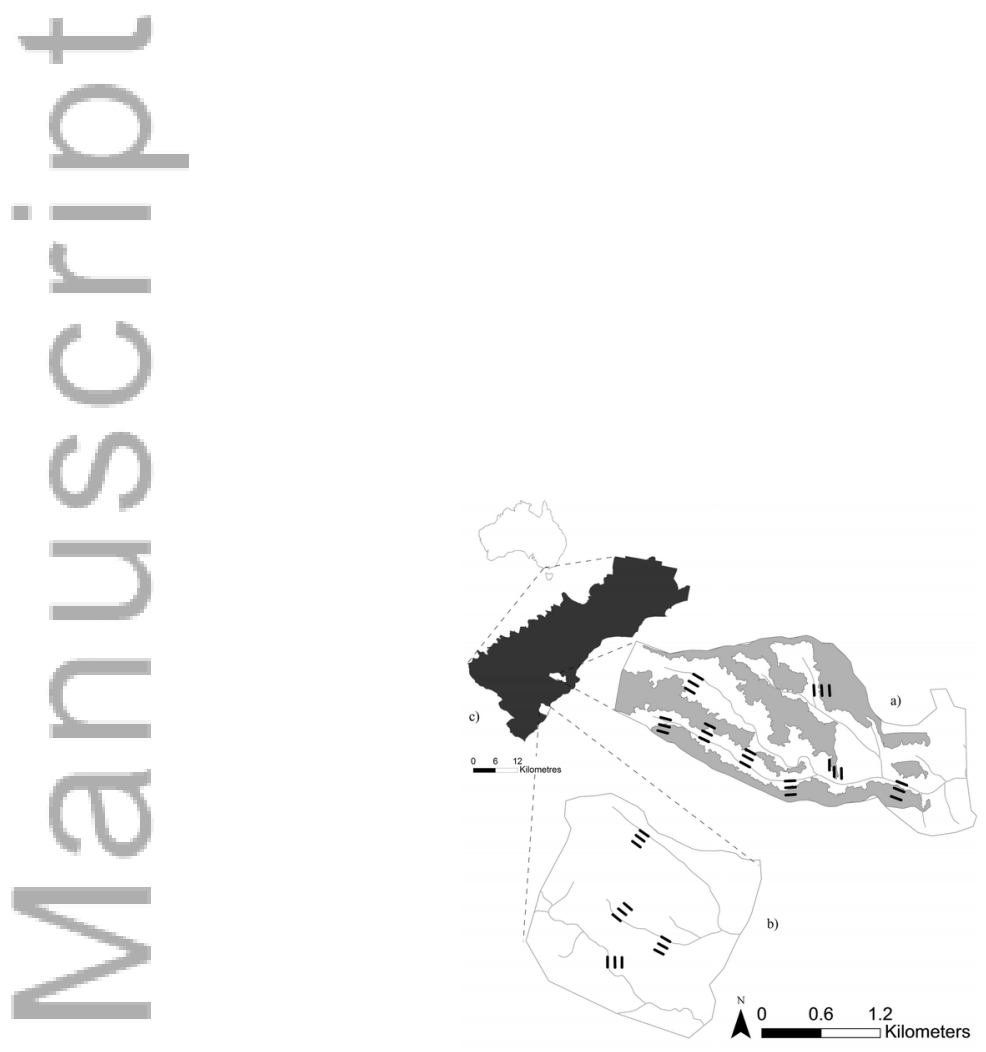

AEC_12331_F1.tiff

This article is protected by copyright. All rights reserved. 


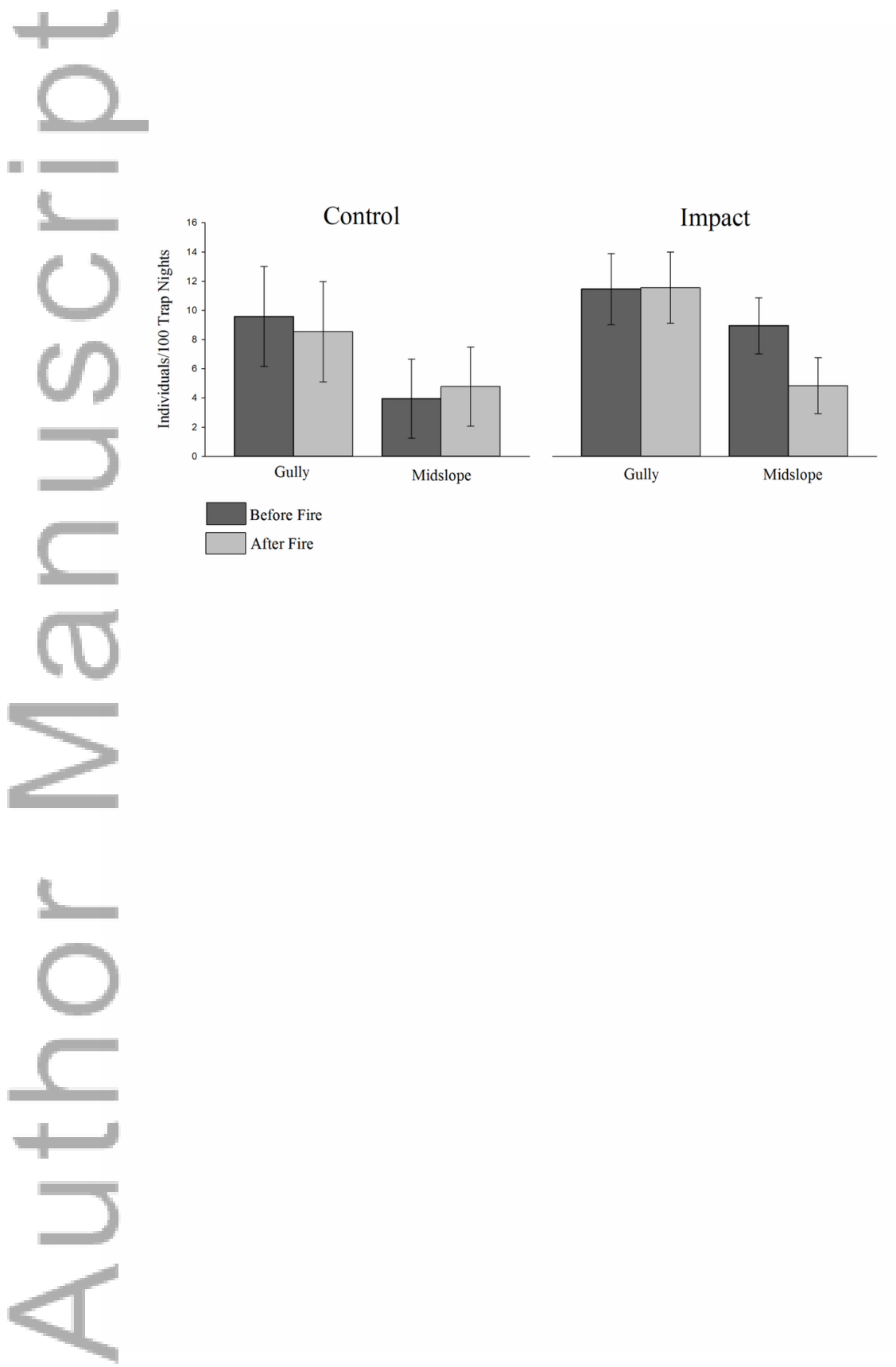

AEC_12331_F2.TIF

This article is protected by copyright. All rights reserved. 


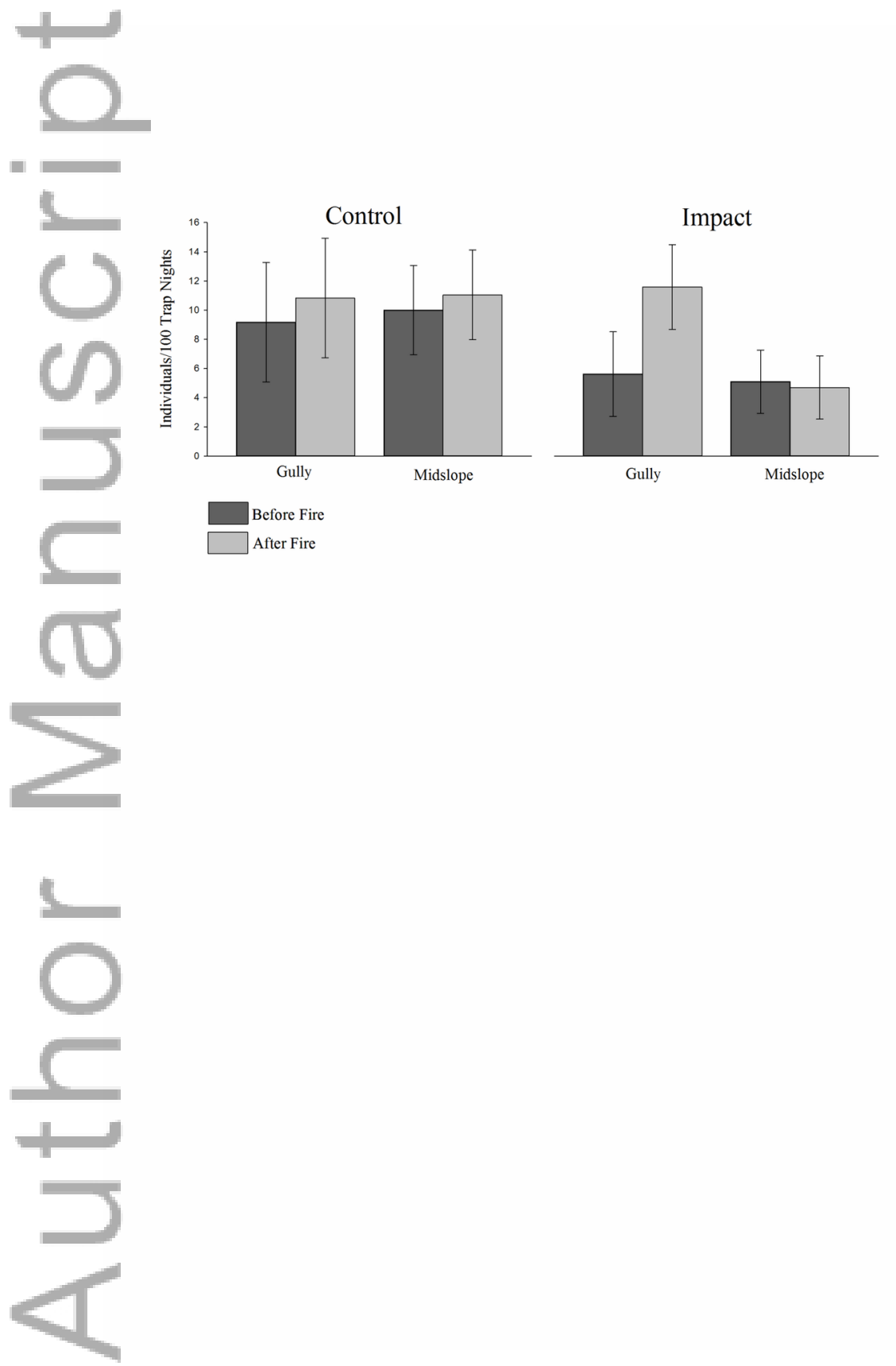

AEC_12331_F3.TIF

This article is protected by copyright. All rights reserved. 

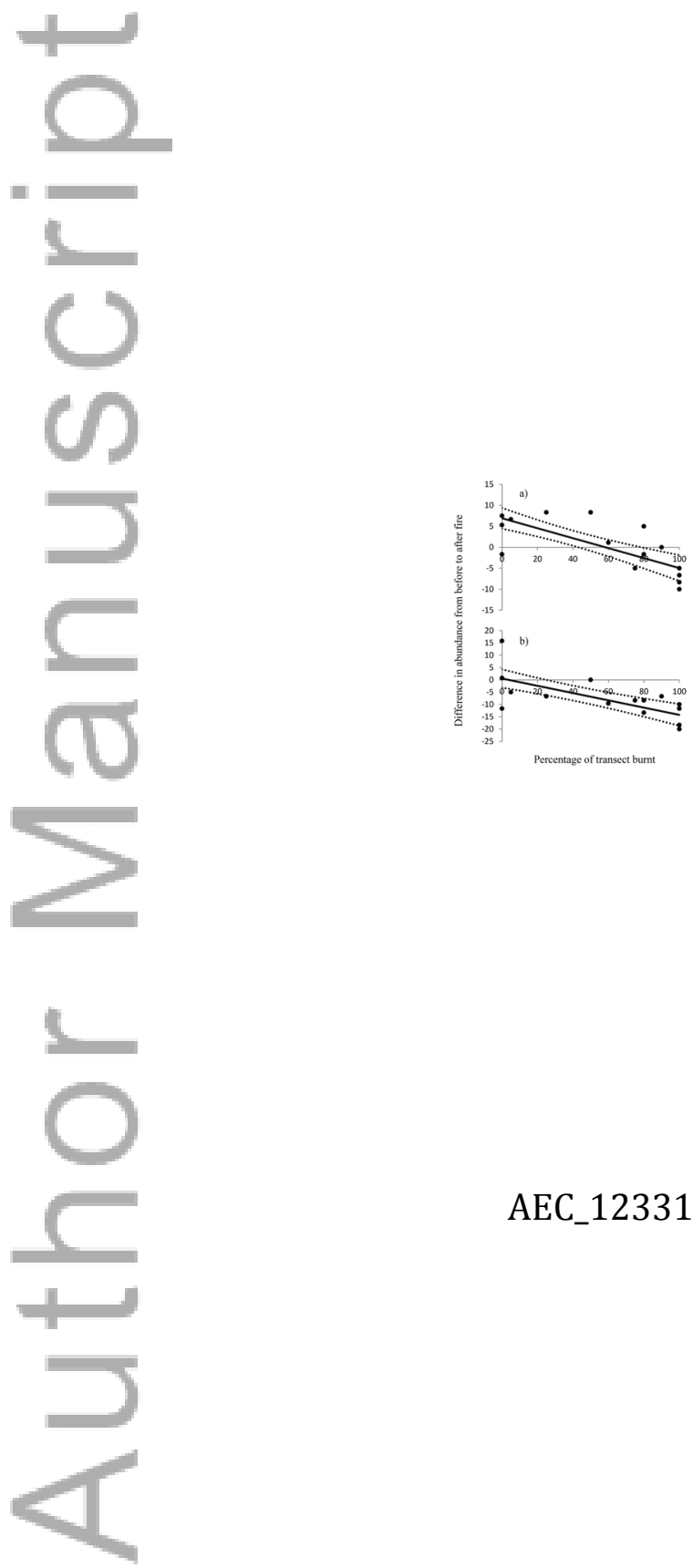

AEC_12331_F4.tiff

This article is protected by copyright. All rights reserved. 


\section{University Library}

\section{- M M N E R VA A gateway to Melbourne's research publications}

Minerva Access is the Institutional Repository of The University of Melbourne

Author/s:

Swan, M;Galindez-Silva, C;Christie, F;York, A;Di Stefano, J

Title:

Contrasting responses of small mammals to fire and topographic refugia

Date:

2016-06-01

Citation:

Swan, M., Galindez-Silva, C., Christie, F., York, A. \& Di Stefano, J. (2016). Contrasting responses of small mammals to fire and topographic refugia. AUSTRAL ECOLOGY, 41 (4), pp.437-445. https://doi.org/10.1111/aec.12331.

Persistent Link:

http://hdl.handle.net/11343/291199 